\title{
p53 Codon 72 Polymorphism in Basal Cell Carcinoma of the Skin
}

\author{
Abdulmohammad PEZESHKI, ${ }^{1}$ Fatemeh SARI-ASLANI, ${ }^{2}$ Abbas GHADERI, ${ }^{1,3}$ Mehrnoosh DOROUDCHI ${ }^{1,3}$ \\ ${ }^{1}$ Shiraz Institute for Cancer Research (ICR), ${ }^{2}$ Department of Pathology, ${ }^{3}$ Department of Immunology, \\ Shiraz University of Medical Sciences, Shiraz, Iran
}

Basal cell carcinoma (BCC) is the most prevalent cancer in Iran. A common polymorphism at codon 72 of exon 4 of p53 tumor suppressor gene has been reported to be associated with increased inheritable susceptibility to several cancers. In the present study the frequency of p53 codon 72 polymorphism in 91 patients with BCC of skin, compared to 465 healthy normal individuals, was investigated. In total, there was no significant difference in the p53 genotypes between patients and controls. However, there was an apparent increase in the Arg/Arg genotype among those BCC patients who had a history of occupational sun exposure, compared to non-exposed patients
(46.3\% vs. $23.1 \%, P=0.11)$. A trend of increase in the frequency of $A r g$ allele among sun-exposed patients was also observed $(69.4 \%$ vs. $53.8 \%, P=0.07)$. Comparison of the genotype frequencies between sunexposed patients and normal controls confirmed the accumulation of $\mathrm{Arg} / \mathrm{Arg}$ genotype in these patients $(46.3 \%$ vs. $34.8 \%, P=0.07)$. In addition, the frequency of Arg allele was significantly higher in sunexposed patients compared to controls $(69.4 \%$ vs. $58.2 \%, \mathrm{P}=0.03$ ). Our results suggest that $\mathrm{Arg}$ allele at codon 72 of 553 gene might affect the risk of ultraviolet-induced basal cell carcinoma. (Pathology Oncology Research Vol 12, No 1, 29-33)

Key words: basal cell carcinoma, p53, polymorphism, sun exposure

\section{Introduction}

Skin cancer is the most common cancer among different populations worldwide. Among the three main types of skin cancer, basal cell carcinoma (BCC) is the most prevalent cancer in Iran, a country populated by a non-European Caucasoid population. The most important risk factor known for skin carcinogenesis is solar UV radiation. ${ }^{1}$ However, there are cumulative data pointing to the importance of genetic factors in susceptibility to the disease. Thus far, mutations and polymorphisms in PTCH and p53 genes have been suggested to play a role in the development of BCC. ${ }^{2}$ Recent reports have shown a significant association between Arg72 homozygosity in p53 tumor suppressor gene and susceptibility to non-melanoma skin cancers in renal transplant patients, mostly in white Cau-

Received: July 5, 2005; accepted: Oct 31, 2005

Correspondence: Mehrnoosh DOROUDCHI, Ph.D., Department of Immunology, Medical School, Shiraz University of Medical Sciences, P.O. Box: 71345-1798, Shiraz, Iran. Tel.: +98-711-2303687, Fax: +98-711-2304952, e-mail: mdoroud@sums.ac.ir casians. ${ }^{3}$ However, there is no report on this polymorphism in the darker-skinned populations which are significantly resistant to the effects of sunlight.

The polymorphism is a $\mathrm{G} / \mathrm{C}$ substitution in codon 72 of p53 gene, which results in an Arg/Pro change in the sequence of encoded amino acids. ${ }^{4}$ The Arg/Pro polymorphism occurs in a proline-rich domain and results in alteration of electrophoretic mobility of the protein. ${ }^{5,6}$ The codon 72 polymorphism has also been shown to affect the behavior of certain p53 mutants and their potential of transforming cells. ${ }^{7,8}$ In the presence of Arg allele, conformational p53 mutants have been more potent in binding to p73 and neutralizing p73-induced apoptosis, ${ }^{7}$ which enhances tumorigenesis and provides a selective growth advantage to tumor cells. ${ }^{8}$ Increased susceptibility of $A r g 72$ containing p53 protein to degradation by human papillomavirus (HPV) has also been reported. ${ }^{9}$ In this regard, a strong association of Arg72 homozygosity with HPV-induced cervical cancer has been suggested. ${ }^{10-}$ ${ }^{13}$ In addition, a selective retention of Arg72 alleles and a higher aggressiveness of Arg72-containing ovarian tumors have been shown. ${ }^{14}$ However, the issue is still 
controversial in some other types of cancers and in some ethnic groups. ${ }^{15-20}$

This study was undertaken to investigate the association of p53 codon 72 polymorphism with $\mathrm{BCC}$ in southern Iranian patients.

\section{Patients and Methods}

In this study we investigated the frequency of p53 codon 72 polymorphism in 91 patients with BCC of skin, compared to 465 ethnically-matched healthy blood donors. Peripheral blood samples were collected in $10 \mathrm{ml}$ volume by venous puncture method, and genomic DNA was extracted from peripheral blood lymphocytes by salting out method. The extracted DNA was examined by an allele-specific polymerase chain reaction described by Soulitzis et al. ${ }^{21}$ To detect the p53 codon 72 polymorphism, two primer sets in separate tubes were used, one to amplify the Arg allele and the other to amplify the Pro allele as follows: $\operatorname{ArgF}$ : TCC CCC TTg CCg TCC CAA, $\operatorname{ArgR}$ : CTg gTg Cag ggg CCA CgC, ProF: gCC AgA ggC TgC TCC CCC, ProR: CgT gCA AgT CAC AgA CCT.

Each set of primers were used in a different tube in a total volume of $25 \mu \mathrm{l}$ containing $0.3 \mathrm{mM}$ dNTPs, $1.5 \mathrm{mM}$ $\mathrm{MgCl}_{2}, 2 \mathrm{U}$ Taq DNA polymerase (Sinagen, Iran) and $1 \mathrm{x}$ buffer $(20 \mathrm{mM}$ Tris- $\mathrm{HCl}, \mathrm{pH} 8.4$ and $50 \mathrm{mM} \mathrm{KCl})$. The amplification was performed for 35 cycles under a touchdown program; by denaturation at $94^{\circ}$ for $30 \mathrm{~s}$, annealing at $68^{\circ} \mathrm{C}$ to $62^{\circ} \mathrm{C}$ for ten cycles and $62^{\circ} \mathrm{C}$ to $58^{\circ} \mathrm{C}$ for 25 cycles, and extension at $72^{\circ} \mathrm{C}$ for $30 \mathrm{~s}$ in each cycle. The PCR product of the Arg allele was $141 \mathrm{bp}$, while the product of the Pro allele was 177 bp (Figure 1).

At the time of blood sampling, demographic and clinical data were recorded in a questionnaire. The location of lesions, number of lesions, history of occupational sun exposure and history of malignancies were also recorded.

The calculated frequencies were analyzed by Chisquare test using EPI-info 2000 and SPSS 10.0 for Windows software.

\section{Results}

In total 58 male and 33 female BCC patients were studied of which 54 individuals had a history of occupational sun exposure. Mean age of patients was found to be 59.16 \pm 1.37 years and median age of patients was 59 years. The mean age at diagnosis was $57.70 \pm 1.87$ years and median age at diagnosis was 59 years. Twenty-nine $(31.87 \%)$ out of 91 patients were farmers. The number of lesions varied from 1 to 11 with different sizes. Table 1 shows the patients' information.

In total, 34 (37.4\%) BCC patients and 162 (34.8\%) normal individuals had Arg/Arg genotype, while 10 (11\%) BCC patients and $86(18.5 \%)$ normal individuals had

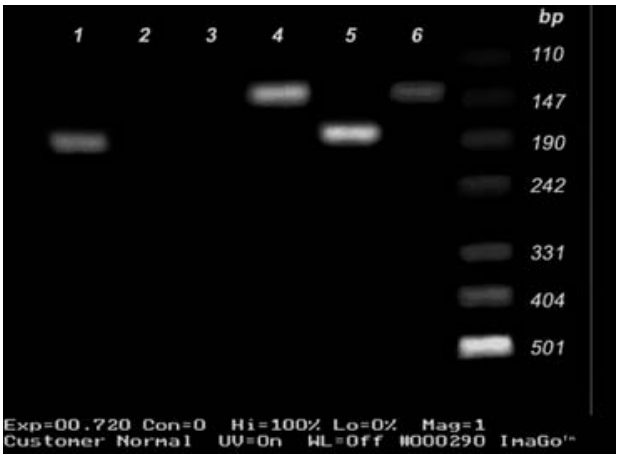

Figure 1. PCR amplification of the p53 codon 72 Arg allele (141 bp) and Pro allele (177 bp). The result of amplification for Pro homozygote (lanes 1 and 2), Arg homozygote (lanes 3 and 4) and Pro/Arg heterozygote (lanes 5 and 6) genotypes are indicated. The reaction in lane 1 (Pro) and lack of reaction in lane 2 $(A r g)$ indicate that the first individual is Pro homozygote, while lack of reaction in lane 3 (Pro) and the existence of PCR-amplified Arg band in lane 4 indicate that individual 2 is Arg homozygote. The reaction in both lanes (5 and 6) indicates that individual 3 is heterozygote.

Pro/Pro genotype. The frequencies of heterozygous BCC and healthy individuals were $47(51.6 \%)$ and 217 $(46.7 \%)$, respectively. There was no significant difference in the frequencies of p53 alleles and genotypes between patients and controls (Table 2, $\mathrm{P}=0.24$ and $\mathrm{P}=0.22$ ). However, there was an apparent increase in Arg/Arg genotype among those BCC patients who had a history of occupational sun exposure compared to non-exposed patients ( $46.3 \%$ vs. $23.1 \%, \mathrm{P}=0.11)$. A trend of increase in the frequency of Arg allele among sun-exposed patients was also observed (69.4\% vs. $53.8 \%, \mathrm{P}=0.07)$. Among the control group, 64 had a history of occupational sun exposure, for which the frequencies of $\mathrm{Arg} / \mathrm{Arg}$ and Pro/Pro genotypes were found to be $21(32.8 \%)$ and $10(15.6 \%)$, respectively. The frequencies of these genotypes in sun-exposed patients were found to be $25(46.3 \%)$ and $4(7.4 \%)$, respectively. In this regard, an increase in the Arg/Arg genotype and a decrease in Pro/Pro genotype among patients was observed, but did not reach statistical significance $(\mathrm{P}=0.2)$. Comparison of the allele frequencies revealed an increase in the Arg allele and a decrease in Pro allele among sun-exposed patients compared to sunexposed healthy individuals. However, the difference was not statistically significant $(\mathrm{P}=0.11)$.

Comparison of the genotype frequencies between sunexposed patients and normal controls confirmed the accumulation of $\mathrm{Arg} / \mathrm{Arg}$ genotype in these patients (46.3\% vs. $34.8 \%, \mathrm{P}=0.07$ ). In addition, the frequency of Arg allele was significantly higher in sun-exposed patients compared to controls $(69.4 \%$ vs. $58.2 \%, \mathrm{P}=0.03)$.

The genotype and allele frequencies were also compared between 63 control individuals aged more than 45 years 
and the 91 patients. There was no significant difference in the frequencies between patients and age-matched controls $(\mathrm{P}=0.73)$. Table 3 shows the genotype frequencies of this comparison. There was also no significant difference in the frequency of codon 72 polymorphism between patients and controls in regard to age, gender, number of lesions, location of lesion, exposure of lesion, history of recurrence and history of skin malignancy. There was also no significant difference in the studied frequencies between patients who lived in rural and urban areas.

\section{Discussion}

Our results are in accordance with previous reports suggesting that there is no direct association between p53 codon 72 polymorphism and $\mathrm{BCC}$ in immunocompetent patients. ${ }^{3}$ However, the comparison of the sun-exposed patients with control healthy individuals revealed a significant difference in the frequency of Arg allele and a marginal difference in the frequency of $\mathrm{Arg} / \mathrm{Arg}$ genotype. A non-significant increase both in the Arg/Arg genotype

Table 1. Characteristics of patients

\begin{tabular}{|c|c|c|c|c|c|}
\hline & Number & $\%$ & & Number & $\%$ \\
\hline Gender & & & \multicolumn{3}{|c|}{ Approximate diameter of lesion ( $\mathrm{mm})$} \\
\hline Male & 58 & 63.7 & 4 & 1 & 1.1 \\
\hline Female & 33 & 36.3 & 5 & 20 & 21.9 \\
\hline Occupation & & & $\begin{array}{l}8 \\
9\end{array}$ & $\begin{array}{l}5 \\
6\end{array}$ & $\begin{array}{l}5.5 \\
6.6\end{array}$ \\
\hline Farmer & 29 & 31.9 & 10 & 19 & 20.9 \\
\hline Housewife & 13 & 14.3 & 15 & 12 & 13.2 \\
\hline Teacher/Clerk & 8 & 8.8 & 20 & 8 & 8.8 \\
\hline Worker & 8 & 8.8 & 25 & 2 & 2.2 \\
\hline Driver & 7 & 7.7 & 30 & 4 & 4.4 \\
\hline Army officer & 6 & 6.6 & 40 & 2 & 2.2 \\
\hline Other & 13 & 14.2 & 50 & 2 & 2.2 \\
\hline ND & 7 & 7.7 & 75 & 1 & 1.1 \\
\hline & & & 100 & 1 & 1.1 \\
\hline Lesion exposure & & & ND & 8 & 8.8 \\
\hline Sun-exposed & 72 & 79.1 & & & \\
\hline Non-exposed & 9 & 9.9 & \multirow{4}{*}{$\begin{array}{l}\text { Recurrence } \\
\text { Yes } \\
\text { No } \\
\text { ND }\end{array}$} & & \\
\hline Both & 2 & 2.2 & & 14 & 15.4 \\
\hline ND & 8 & 8.8 & & 44 & 48.3 \\
\hline $\begin{array}{ll}x \\
\end{array}$ & & & & 33 & 36.3 \\
\hline Location of lesions & & & & & \\
\hline Nose & 25 & 27.4 & \multicolumn{2}{|l|}{ Skin malignancy } & \\
\hline Head & 14 & 15.4 & Yes & 3 & 3.3 \\
\hline Cheeks & 11 & 12.1 & No & 47 & 51.6 \\
\hline Eye & 5 & 5.5 & ND & 41 & 45.1 \\
\hline Temple & 5 & 5.5 & & & \\
\hline Forehead & 4 & 4.4 & \multicolumn{2}{|l|}{ Sunscreen use } & \\
\hline Ear & 4 & 4.4 & Yes & 4 & 4.4 \\
\hline Arm & 3 & 3.3 & No & 59 & 64.8 \\
\hline Chin & 1 & 1.1 & ND & 28 & 30.8 \\
\hline Underarm & 1 & 1.1 & 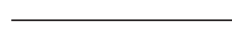 & & \\
\hline Breast & 1 & 1.1 & \multicolumn{2}{|l|}{ Living area } & \\
\hline Other & 11 & 12.1 & \multirow{3}{*}{$\begin{array}{l}\text { Rural } \\
\text { Urban } \\
\text { ND }\end{array}$} & 37 & 40.7 \\
\hline ND & 6 & 6.6 & & 42 & 46.1 \\
\hline & & & & 12 & 13.2 \\
\hline $\begin{array}{l}\text { Number of lesions } \\
1\end{array}$ & 67 & 73.6 & \multirow{6}{*}{ Total } & \multirow{6}{*}{91} & \multirow{6}{*}{100} \\
\hline 2 & 7 & 7.7 & & & \\
\hline 3 & 7 & 7.7 & & & \\
\hline 5 & 3 & 3.3 & & & \\
\hline 11 & 1 & 1.1 & & & \\
\hline ND & 6 & 6.6 & & & \\
\hline
\end{tabular}

ND: Not determined 
Table 2. Genotype and allele frequencies in patients and controls

\begin{tabular}{lccccr}
\hline & Arg/Arg & Pro/Pro & Arg/Pro & Arg & Pro \\
\hline Patients & 34 & 10 & 47 & 115 & 67 \\
Controls & 162 & 86 & 217 & 541 & 389 \\
\hline & & $\mathrm{P}=0.22$ & & \multicolumn{2}{c}{$\mathrm{P}=0.24$} \\
\hline
\end{tabular}

Table 3. Genotype frequencies in patients and agematched controls

\begin{tabular}{lccc}
\hline & Arg/Arg & Pro/Pro & Arg/Pro \\
\hline Patients & 34 & 10 & 47 \\
Controls & 25 & 9 & 29 \\
\hline & & P $=0.73$ & \\
\hline
\end{tabular}

and in the Arg allele frequency among sun-exposed patients compared to the non-exposed patients was also obvious. The most important risk factor of $\mathrm{BCC}$ is solar UV radiation as for other skin malignancies..$^{22}$ Ethnicity, color of unexposed skin, latitude, pattern and amount of sun exposure, other radiations, Arsenic exposure, Xeroderma pigmentosum, Bazex syndrome, and Gorlin's syndrome are other minor risk factors in the common population. ${ }^{23}$ As can be seen among the sunlight non-exposed patients of this study, the effect of sunlight and Arg allele have simultaneously decreased. Therefore, the significance of this allele is highlighted when interacting environmental factors are taken into consideration.

Environmental UV exposure is an early event in skin carcinogenesis, which can induce harmful mutations in the p53 gene. ${ }^{24}$ This is in part related to the abundance of high UV absorbent conjugated bonds in the structure of DNA. ${ }^{25}$ Among BCC patients, UVB signature point mutations occur frequently in the p53 gene. ${ }^{26}$ A dysfunctional p53 protein will lose its tumor suppressive and cell cycle arrest-inducing effects. In addition, the mutated protein will be non-functional or less functional in apoptosis induction. An inherent Arg allele which acquires mutations after epigenetic interference is more likely to inhibit downstream apoptotic pathways. ${ }^{7}$ Therefore, the risk of p53 codon 72 polymorphism comes into existence when epigenetic factors such as UV radiation and HPV virus infection are taken into consideration. ${ }^{11,13}$ This effect might be more important when recessive less functional p53 mutants are present in the tumor cells. ${ }^{8}$ As it has been reported, presence of $A r g 72$ in the mutant allele or preferential retention of Arg72 allele in the tumoral tissue (Arg bias) provides a selective growth advantage to tumor cells during the stage of tumorigenesis. ${ }^{8}$
$\mathrm{BCC}$ of the skin is the most common cancer in humans worldwide, and is mainly considered a disease of fairskinned people. ${ }^{27}$ The estimated prevalence of skin cancers in Fars province has been reported to be 9.7 in 100,000, which comprises $18.3 \%$ of the total registered cancers in this area. ${ }^{28} \mathrm{BCC}$ accounts for $68 \%$ of all registered skin cancers in this area, ${ }^{28}$ in which the most important type of high and long-term solar UV exposure is occupational sun exposure. p53 codon 72 polymorphism shows a latituderelated distribution; i.e., higher prevalence of Pro allele in high latitude areas. It is usually concluded that darkskinned populations have a higher frequency of the Pro allele. In our study the frequencies of the Pro allele (41.8\%) and Pro/Pro genotype (18.5\%) in normal individuals were lower than that of Arg allele and Arg/Arg genotype. These frequencies are very close to the reported frequencies from Greece, ${ }^{29}$ and are consistent with the northsouth pattern of Pro allele distribution. ${ }^{30}$ However, this is most likely to be associated with the genes and not with skin color itself, as none of our patients had a fair-skinned phenotype, although this phenotype is not rare among Iranians. These results are consistent with the study of Armstrong et al. in which a weak evidence of increase in risk of $\mathrm{BCC}$ with increasing fairness of the skin was reported. ${ }^{30}$

In conclusion, our results suggest that $\mathrm{Arg} 72$ allele might affect the risk of occupational UV-induced BCC in Iranian population.

\section{Acknowledgement}

This work was financially supported by a grant (grant number 80 1227) from Shiraz University of Medical Sciences.

\section{References}

1. de Gruijl FR, van Kranen HJ, Mullenders LH: UV-induced DNA damage, repair, mutations and oncogenic pathways in skin cancer. J Photochem Photobiol 63: 19-27, 2001

2. Kim MY, Park HJ, Baek SC, et al: Mutations of the p53 and PTCH gene in basal cell carcinomas: UV mutation signature and strand bias. J Dermatol Sci 29: 1-9, 2002

3. McGregor JM, Harwood CA, Brooks L, et al: Relationship between p53 codon 72 polymorphism and susceptibility to sunburn and skin cancer. J Invest Dermatol 119: 84-90, 2002

4. Murata M, Tagawa M, Kimura M, et al: Analysis of a germ line polymorphism of the p53 gene in lung cancer patients; discrete results with smoking history. Carcinogenesis 17: 261-264, 1996

5. Dumont P, Leu JI, Della Pietra AC, et al: The codon 72 polymorphic variants of p53 have markedly different apoptotic potential. Nat Genet 33: 357-365, 2003

6. Buchman VL, Chumakov PM, Ninkina NN, et al: A variation in the structure of the protein-coding region of the human p53 gene. Gene 70: 245-252, 1988

7. Marin MC, Jost CA, Brooks LA, et al: A common polymorphism acts as an intragenic modifier of mutant p53 behaviour. Nat Genet 25: 47-54, 2000

8. Tada $M$, Furuuchi $K$, Kaneda $M$, et al: Inactivate the remaining p53 allele or the alternate p73? Preferential selection of 
the Arg72 polymorphism in cancers with recessive p53 mutants but not transdominant mutants. Carcinogenesis 22: 515-517, 2001

9. Marshall SE, Bordea C, Wojnarowska F, et al: p53 codon 72 polymorphism and susceptibility to skin cancer after renal transplantation. Transplantation 69: 994-996, 2000

10. Makni H, Franco EL, Kaiano J, et al: p53 polymorphism in codon 72 and risk of human papillomavirus-induced cervical cancer: effect of inter-laboratory variation. Int J Cancer 87: 528-533, 2000

11. Nagpal JK, Sahni S, Das BR: p53 codon 72 polymorphism and susceptibility to development of human papilloma virus-associated cervical cancer in Indian women. Eur J Clin Invest 32: 943-948, 2002

12. Qie $M$, Zhang $Y, W u J$ : Study on the relationship between cervical cancer and p53 codon 72 polymorphism. Hua Xi Yi Ke Da Xue Xue Bao 33: 274-275, 2002

13. Li T, Lu ZM, Guo M, et al: p53 codon 72 polymorphism $(\mathrm{C} / \mathrm{G})$ and the risk of human papillomavirus-associated carcinomas in China. Cancer 95: 2571-2576, 2002

14. Pegoraro RJ, Moodley M, Rom L, et al: p53 codon 72 polymorphism and BRCA 1 and 2 mutations in ovarian epithelial malignancies in black South Africans. Int J Gynecol Cancer 13: 444-449, 2003

15. Suzuki K, Matsui H, Ohtake N, et al: A p53 codon 72 polymorphism associated with prostate cancer development and progression in Japanese. J Biomed Sci 10: 430-435, 2003

16. Cenci $M$, French D, Pisani T, et al: p53 polymorphism at codon 72 is not a risk factor for cervical carcinogenesis in central Italy. Anticancer Res 23: 1385-1387, 2003

17. Abba MC, Villaverde LM, Gomez MA, et al: The p53 codon 72 genotypes in HPV infection and cervical disease. Eur J Obstet Gynecol Reprod Biol 109: 63-66, 2003

18. Anzola M, Cuevas $N$, Lopez-Martinez $M$, et al: Frequent loss of p53 codon 72 Pro variant in hepatitis $C$ virus-positive carriers with hepatocellular carcinoma. Cancer Lett 193: 199-205, 2003
19. Buyru N, Budak M, Yazici H, Dalay N: p53 gene mutations are rare in human papillomavirus-associated colon cancer. Oncol Rep 10: 2089-2092, 2003

20. Humbey O, Cairey-Remonnay S, Guerrini JS, et al: Detection of the human papillomavirus and analysis of the TP53 polymorphism of exon 4 at codon 72 in penile squamous cell carcinomas. Eur J Cancer 39: 684-690, 2003

21. Soulitzis $N$, Sourvinos $G$, Dokianakis DN, Spandidos DA: p53 codon 72 polymorphism and its association with bladder cancer. Cancer Lett 179: 175-183, 2002

22. International Agency for Research on Cancer: Solar and Ultraviolet Radiation, vol. 55, International Agency for Research on Cancer, Lyon, 1992

23. Weihrauch $M$, Bader $M$, Lehnert $G$, et al: Carcinogen-specific mutation pattern in the p53 tumor suppressor gene in UV radiation-induced basal cell carcinoma. Int Arch Occup Environ Health 75: 272-276, 2002

24. Ananthaswamy HN, Loughlin SM, Cox $P$, et al: Sunlight and skin cancer: inhibition of p53 mutations in UV-irradiated mouse skin by sunscreens. Nat Med 3: 510-514, 1997

25. Feynman RP, Leighton SM, In: The Feynman lectures on Physics, Vol. III. Addison-Weseley, Reading, MA, 1967, pp.15-7-15-12

26. Ziegler $A D$, Leffel DJ, Kunala $S$, et al: Mutation hotspots due to sunlight in the p53 gene of non-melanoma skin cancers. Proc Natl Acad Sci USA 90: 4216-4220, 1993

27. Farahmandbeigi $M$, Kadivar MR: The incidence rate of registered cancers in Fars province. Disease Control Unit, Shiraz University Press, Iran, 2000

28. Baron JA, Greenberg ER: Prevention of non-melanoma skin cancer. Arch Dermatol 136: 245-246, 2000

29. Argorastos T, Lambropoulos AF, Constantinidis TC, et al: p53 codon 72 polymorphism and risk of intra-epithelial and invasive cervical neoplasia in Greek women. Eur J Cancer Prev 9: 113-118, 2000

30. Armstrong BK, Kricker A: The epidemiology of UV induced skin cancer. $J$ Photochem Photobiol B 63: 8-18, 2001 